\title{
Seasonality and daily flight activity of stable flies (Diptera: Muscidae) on dairy farms in Saraburi Province, Thailand
}

\author{
Jumnongjit Phasuk $^{1 *}$, Atchariya Prabaripai ${ }^{2}$ and Theeraphap Chareonviriyaphap ${ }^{3}$ \\ 1 Department of Parasitology, Faculty of Veterinary Medicine, Kasetsart University, Bangkok 10900, Thailand \\ 2 Department of Mathematics, Statistics and Computer, Faculty of Liberal Arts and Science, Kasetsart University, Kamphaengsean, \\ Nakhon Pathom 73140, Thailand \\ 3 Department of Entomology, Faculty of Agriculture, Kasetsart University, Bangkok 10900, Thailand
}

Received 6 November 2012, Accepted 27 April 2013, Published online 15 May 2013

\begin{abstract}
Knowledge of seasonal abundance and flight activity patterns are required to design effective management programs for insect pests of humans and livestock. In this study, the seasonality and daily flight activity of Stomoxys species were observed on two dairy farms in Saraburi Province, Thailand. Data were assessed throughout 1 year using Vavoua traps from September 2010 to August 2011. A total of 2,520 individuals belonging to four species were collected. Most Stomoxys species peaked in September (rainy season) and gradually decreased in number toward February (dry season); a second peak occurred between March and April (hot season). Stomoxys calcitrans was caught throughout the year and was the most abundant species in this study. The total number of males and females of $S$. calcitrans differed significantly among seasons and time intervals. The weather parameters of relative humidity and light intensity were significantly correlated with $S$. calcitrans abundance.
\end{abstract}

Key words: Stomoxys, daily flight activity, dairy cattle, seasonal abundance, stable flies, Thailand.

\begin{abstract}
Résumé - Saisonnalité et activité de vol quotidienne des mouches d'étables (Diptera : Muscidae) dans des fermes laitières de la province de Saraburi, Thaïlande. La connaissance de l'abondance saisonnière et des patrons d'activité en vol est nécessaire pour établir des programmes efficaces de contrôle des insectes nuisibles a l'homme et au bétail. Dans cette étude, les variations saisonnières et l'activité en vol quotidienne des espèces de Stomoxys ont été observées dans deux fermes laitières de la province de Saraburi, Thaïlande. Les données ont éte obtenues pendant un an en utilisant des pièges Vavoua de septembre 2010 à août 2011. Un total de 2,520 individus appartenant à quatre espèces a été récolté. La plupart des espèces de Stomoxys avaient un pic d'abondance en septembre (saison humide) et leur nombre décroissait régulièrement jusqu'en février (saison sèche) ; un deuxième pic apparaissait entre mars et avril (saison chaude). Stomoxys calcitrans a été capturé toute l'année et était l'espèce la plus abondante dans cette étude. Le nombre total de mâles et de femelles de $S$. calcitrans différait significativement selon les saisons et les intervalles de temps. Les paramètres climatiques d'humidité relative et d'intensité lumineuse étaient corrélés de manière significative avec l'abondance de $S$. calcitrans.
\end{abstract}

\section{Introduction}

Stable flies belong to the subfamily Stomoxyinae in the family Muscidae (Diptera). Among 18 Stomoxys species described, six species are recorded from Thailand, of which one is cosmopolitan, S. calcitrans (Linnaeus, 1758) $[9,22,24]$. Stable flies resemble house flies but can be easily distinguished by their piercing-sucking mouthparts which are conspicuous, long and project straightforward from under the head.

\footnotetext{
*Corresponding author: Email: fvetjjp@ku.ac.th
}

They are important and widely distributed insect pests of livestock, wildlife and sometimes humans. Adult stable flies of both sexes are blood-sucking flies and cause painful bites and significant blood loss in some animals. High populations of biting activity can reduce animal productivity and disturb feeding resulting in reduced weight gain and milk production [2-5, 23]. Moreover, they may act as both biological and mechanical vectors for pathogens such as trypanosomes [19]. Stable flies may also act as an intermediate host of the nematode Habronema [21]. In Thailand, little is known about the presence of different stomoxyine fly species, their distribution and their biology. However, 


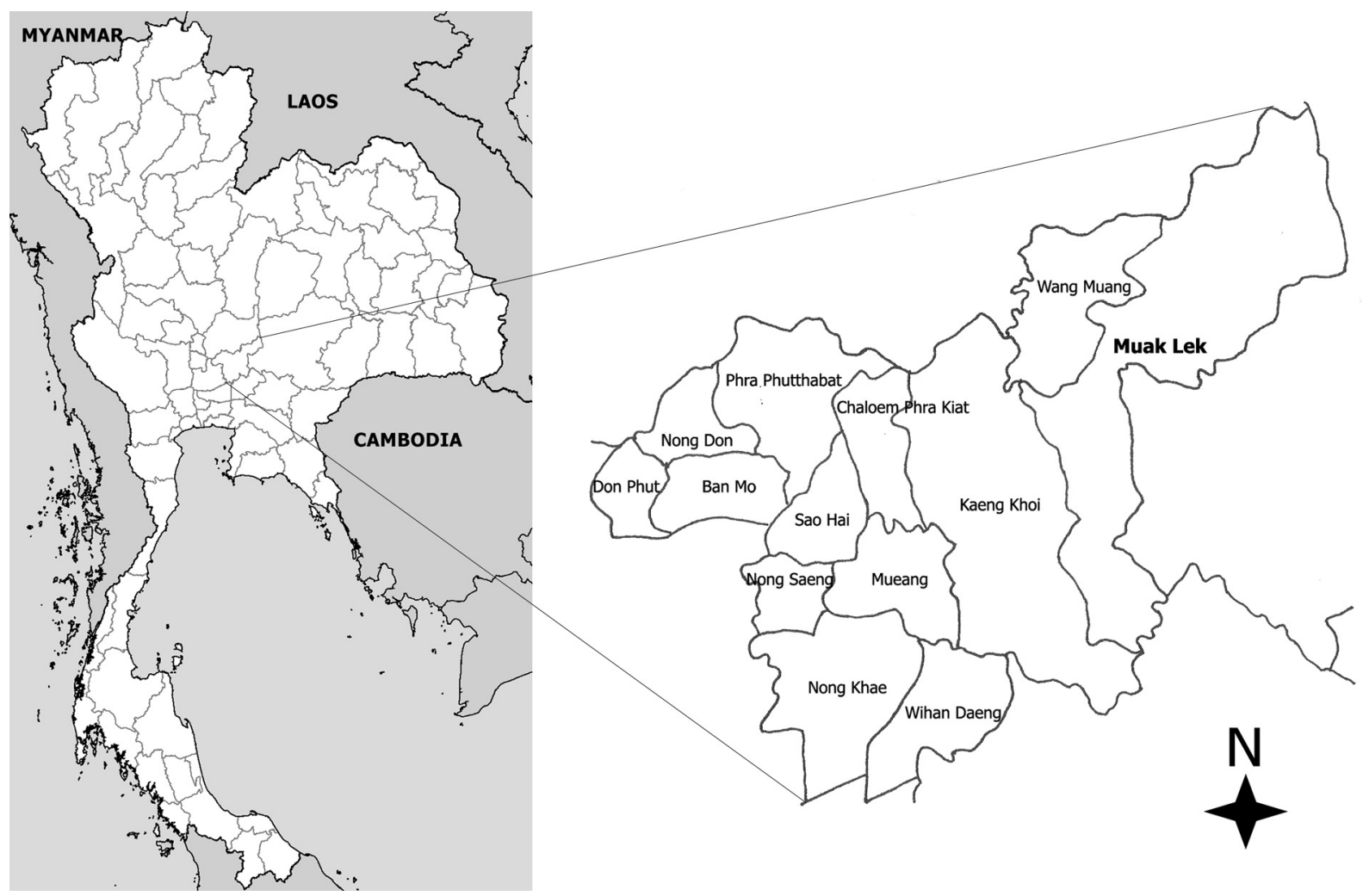

Figure 1. Location of Muak Lek district (study area) in Saraburi Province, Thailand.

Masmeatathip et al. [11] and Muenworn et al. [13] described the seasonal abundance and daily activity of Stomoxys species in Thailand. Muenworn et al. $[12,13]$ conducted stable fly surveys and reported their distribution in Thailand. A better understanding of the seasonal and daily activity of the flies will facilitate and make fly control programs more effective. This study had the objective to evaluate the seasonal abundance and daily activity of Stomoxys species.

\section{Materials and methods}

\section{Study sites}

This study was conducted on two dairy farms in Muak Lek district, Saraburi Province (Figure 1). Saraburi is located in the central highlands of Thailand, an area of relatively high plains and plateaus about $140 \mathrm{~km}$ Northeast of Bangkok. The study sites are 355 and $460 \mathrm{~m}$ above sea level (a.s.l.). Thailand has three seasons: hot (March to May), rainy (June to October) and dry (November to February). At the time of the study, farm $1\left(14^{\circ} 48^{\prime} \mathrm{N}, 101^{\circ} 17^{\prime} \mathrm{E}\right.$; $460 \mathrm{~m}$ a.s.l $)$ had 10 cows and farm $2\left(14^{\circ} 47^{\prime} \mathrm{N}, 101^{\circ} 15^{\prime} \mathrm{E}\right.$; $355 \mathrm{~m}$ a.s.l $)$ had 57 cows in milk production.

\section{Specimen collection}

At each site, four Vavoua traps [8] were randomly installed around sample sites at least $5 \mathrm{~m}$ apart from each other. The traps were placed at $5-10 \mathrm{~cm}$ above the ground. Stable flies were observed monthly during a one-year study (September 2010 to August 2011). Flies were captured every hour between 0600 and $1800 \mathrm{~h}$. After trapping, flies in the Vavoua traps were killed using ethanol spray and preserved in $80 \%$ ethanol. Air temperature, relative humidity and light intensity were also recorded every hour by using a digital thermometer and a digital light meter at each farm. The specimens were brought back to the Department of Parasitology, Faculty of Veterinary Medicine, Kasetsart University, Bangkok, Thailand, for identification using the keys of Zumpt [24] and Tumrasvin \& Shinonaga [22].

\section{Data analysis}

The total numbers of each sex of stable flies collected from traps at each collection site were analyzed using a one-way analysis of variance (ANOVA) and the time intervals were considered as treatment effects. Variations in the numbers of each sex between seasons were compared using the least significant difference (LSD) test. Stepwise multiple regression analysis was used to determine the relationship between the abundance of stable fly species and weather parameters. The data were analyzed using SPSS (Version 17, SPSS Inc., Chicago, IL, USA). All statistical significance levels were set at $p<0.05$.

\section{Results}

In total, 2,520 individuals of Stomoxys species were collected during the one-year study, of which 1,622 were trapped 
Table 1. Total numbers of Stomoxys spp. collected and their relative abundance (RA) on two dairy farms, Muak Lek district, Saraburi Province from September 2010 to August 2011.

\begin{tabular}{|c|c|c|c|c|c|}
\hline Species & Sex & Farm 1 & RA (\%) & Farm 2 & RA (\%) \\
\hline \multirow[t]{2}{*}{ S. bengalensis Picard, 1908} & Male & 0 & 0 & 1 & 0.1 \\
\hline & Female & 0 & 0 & 0 & 0 \\
\hline \multirow[t]{2}{*}{ S. calcitrans (Linnaeus, 1758) } & Male & 1,206 & 74.4 & 535 & 59.6 \\
\hline & Female & 355 & 21.9 & 268 & 29.8 \\
\hline \multirow[t]{2}{*}{ S. indicus Picard, 1908} & Male & 19 & 1.2 & 12 & 1.3 \\
\hline & Female & 34 & 2.1 & 25 & 2.8 \\
\hline \multirow[t]{2}{*}{ S. sitiens Rondani, 1873} & Male & 5 & 0.3 & 24 & 2.7 \\
\hline & Female & 3 & 0.2 & 33 & 3.7 \\
\hline Species/total number & & $3 / 1,622$ & & $4 / 898$ & \\
\hline
\end{tabular}

on farm 1 and 898 on farm 2 (Table 1). The following four species were captured: S. bengalensis Picard, 1908 [15], S. calcitrans (Linnaeus, 1758) [9], S. indicus Picard, 1908 [15] and S. sitiens Rondani, 1873 [17].

The highest temperature was recorded in May and the lowest temperature was in October. The average relative humidity was lower in December to January during the dry season and the highest relative humidity was in September. The average light intensity was high in March to May during the hot season (Figure 2). Seasonal variations in the abundance of Stomoxys species are presented at the species and site levels in Figures 3 and 4. The highest numbers of each species were recorded in September and gradually decreased in number toward February. The second peak of most species occurred between March and April. The most abundant species was S. calcitrans (89$96 \%$ ) which was found on both farms. S. calcitrans was present throughout the year. Collections of other species were too low to be meaningful for the analysis (Table 1 and Figure 7).

On both farms, the numbers of males of $S$. calcitrans were significantly $(p<0.05)$ greater than the females in each season (Figure 5). On farm 1, seasonal variations in the numbers of females were significant $(p<0.05)$, except between the hot and rainy seasons, whereas for males, seasonal variations were significant $(p<0.05)$, except between the hot and dry seasons and the hot and rainy seasons. On farm 2 , seasonal variations in the numbers of both sexes were significant $(p<0.05)$. The abundance of $S$. calcitrans peaked in the rainy season and declined in the dry season.

On farm 1, the total number of females of $S$. calcitrans collected did not differ significantly among time intervals in the dry, hot and rainy seasons. The numbers of males collected showed a significant $(p=0.005)$ difference among time intervals in the dry season, but there was no significant difference among time intervals in the hot and rainy seasons (Figure 6). On farm 2, the total number of females collected showed a significant $(p=0.009)$ difference among time intervals in the rainy season, but there was no significant difference among time intervals in the dry and hot seasons. Males showed significant differences in time intervals between the hot and rainy seasons ( $p=0.007, p=0.028$, respectively), but not in the dry season (Figure 6).

During the whole collection period, S. calcitrans abundance was not related to air temperature but showed a positive correlation with relative humidity and light intensity (Table 2).

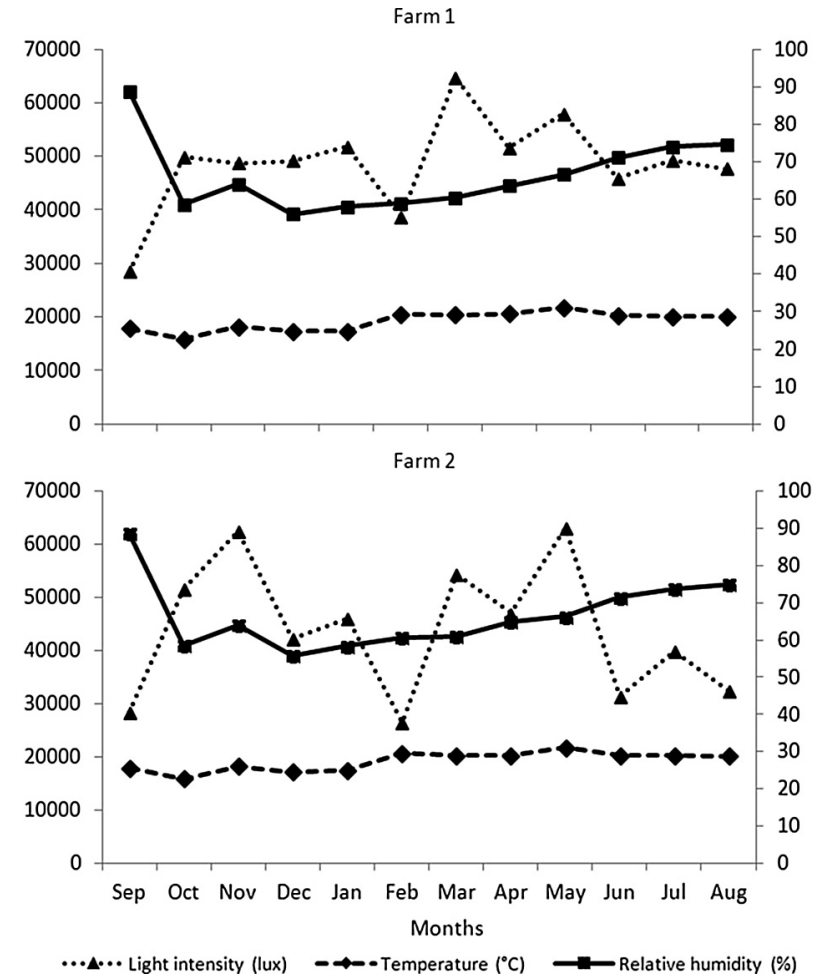

Figure 2. Mean monthly temperature and relative humidity (right axis scale) and light intensity (left axis scale) on the experimental sites (two dairy farms) from September 2010 to August 2011.

\section{Discussion}

The present study extends our understanding of the seasonal abundance and daily activity of stable flies in Thailand. In Saraburi Province, there were four species in the genera Stomoxys collected from both farms and S. calcitrans was active throughout the year. Muenworn et al. [13] found $S$. calcitrans to be the most abundant species followed by $S$. indicus. Stomoxys populations peaked in September, corresponding to the rainy season. This finding agreed with earlier work by Masmeatathip et al. [11] and Muenworn et al. [13]. This may have been due to an increase in the rainfall causing a widespread increase in suitable breeding sites which is a 

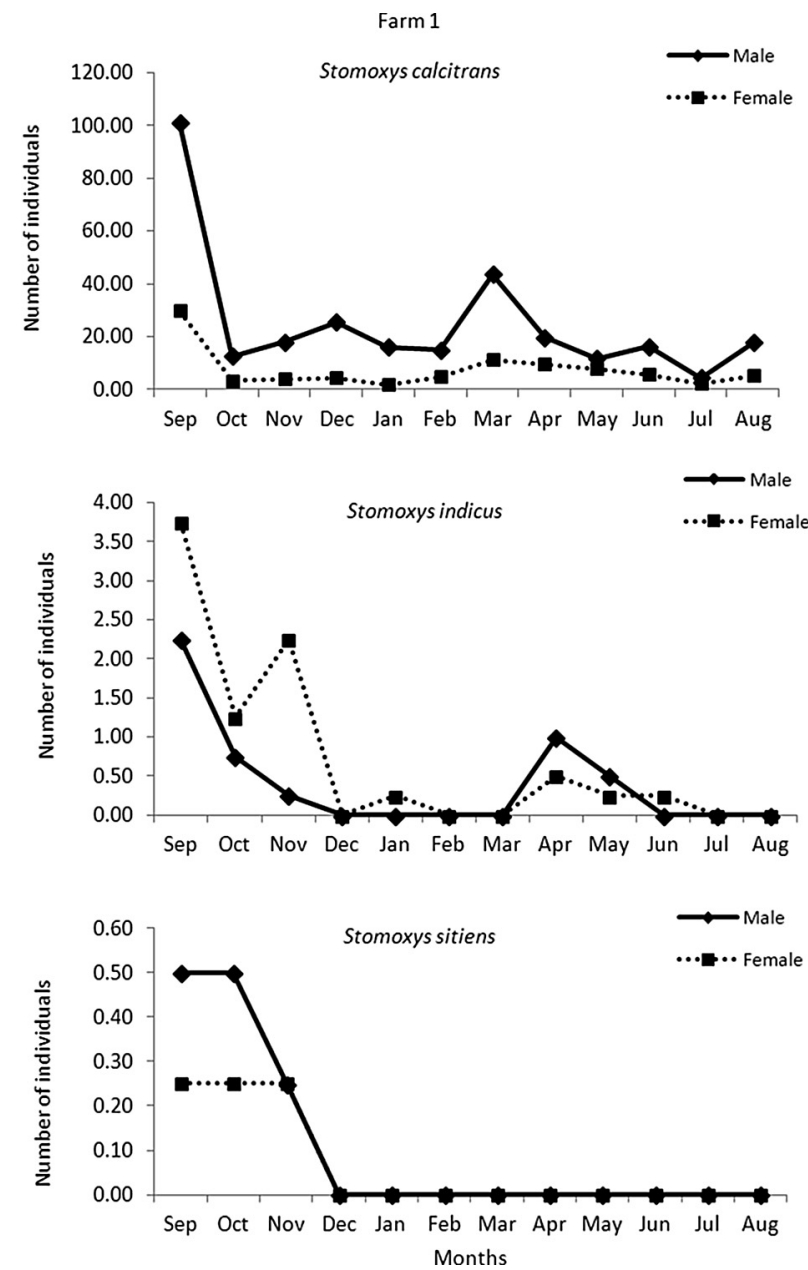

Figure 3. Mean number of Stomoxys spp. captured in four traps on dairy farm 1 from September 2010 to August 2011.

critical factor for eggs to hatch and the larvae to survive and successfully develop to pupae and adults. Earlier work shows that immature stages of Stomoxys (eggs and larvae) are highly sensitive to the following environmental conditions to survive and successfully develop to pupae and adults: temperature, humidity and rainfall $[6,18]$.

The numbers of male $S$. calcitrans were significantly higher than females, in agreement with the reports of Masmeatathip et al. [11] and Muenworn et al. [13]. More female S. indicus were collected than males on both farms. Similar findings were reported by Masmeatathip et al. [11].The sex ratios of $S$. sitiens varied between farms. Only one male of $S$. bengalensis was seen and that was on farm 2 . The variation in the abundance of Stomoxys species that were observed may have depended on the temperature, precipitation, types of trap, trap locations and trap height $[1,7,10,16]$. Further studies are needed to evaluate whether these differences are associated with the location or other factors that attract Stomoxys species.

The season seemed to play a major role in the daily activity patterns of $S$. calcitrans. In the dry and rainy seasons, the number of $S$. calcitrans increased throughout the day until $1500 \mathrm{~h}$ and gradually decreased in number toward $1800 \mathrm{~h}$. In the hot season, this species was present throughout the day and peaked
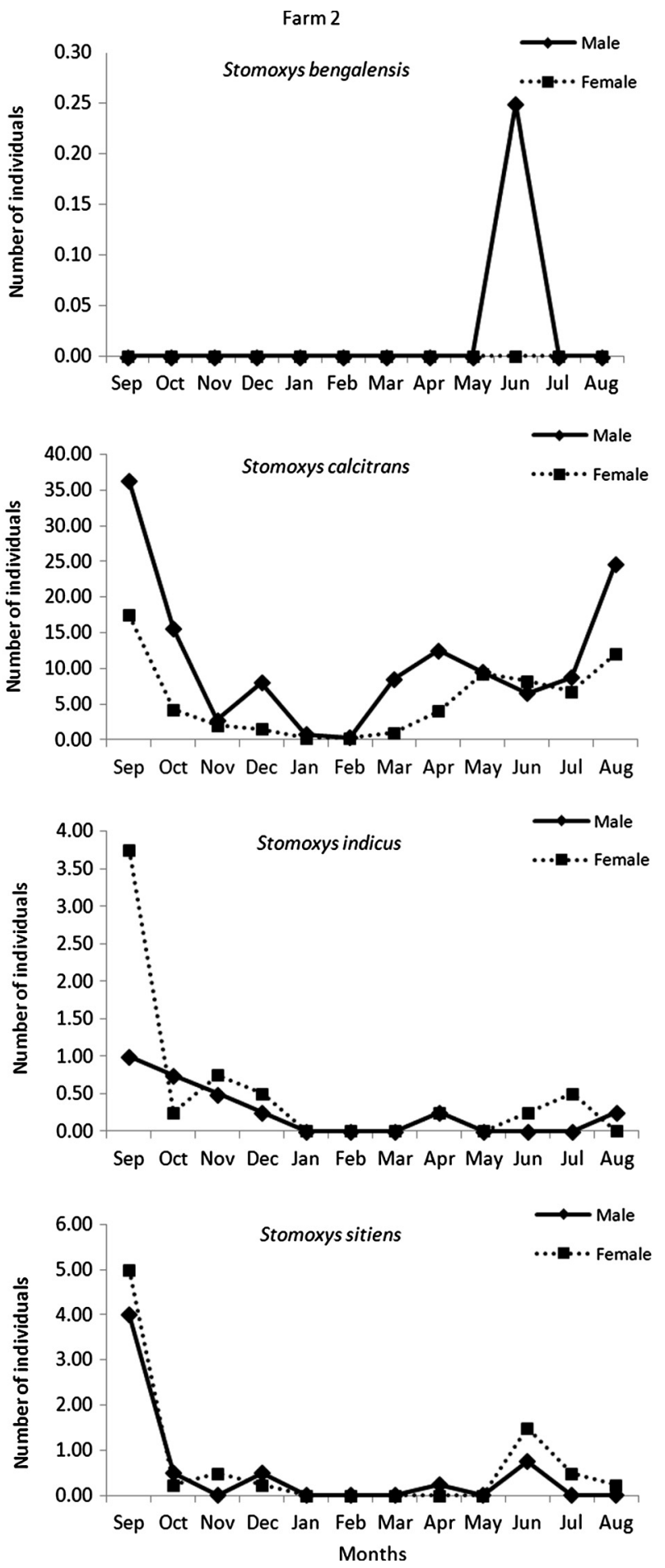

Figure 4. Mean number of Stomoxys spp. captured in four traps on dairy farm 2 from September 2010 to August 2011.

in abundance in the evening and a secondary peak occurred in the late morning although the numbers of females were not statistically significant among the time intervals. In previous studies, S. calcitrans was reported to have a bimodal pattern of feeding with a major peak during 0800-1000 h and a minor peak occurred during the afternoon [11]. Muenworn et al. [13] showed a bimodal activity of male $S$. calcitrans with peaks 

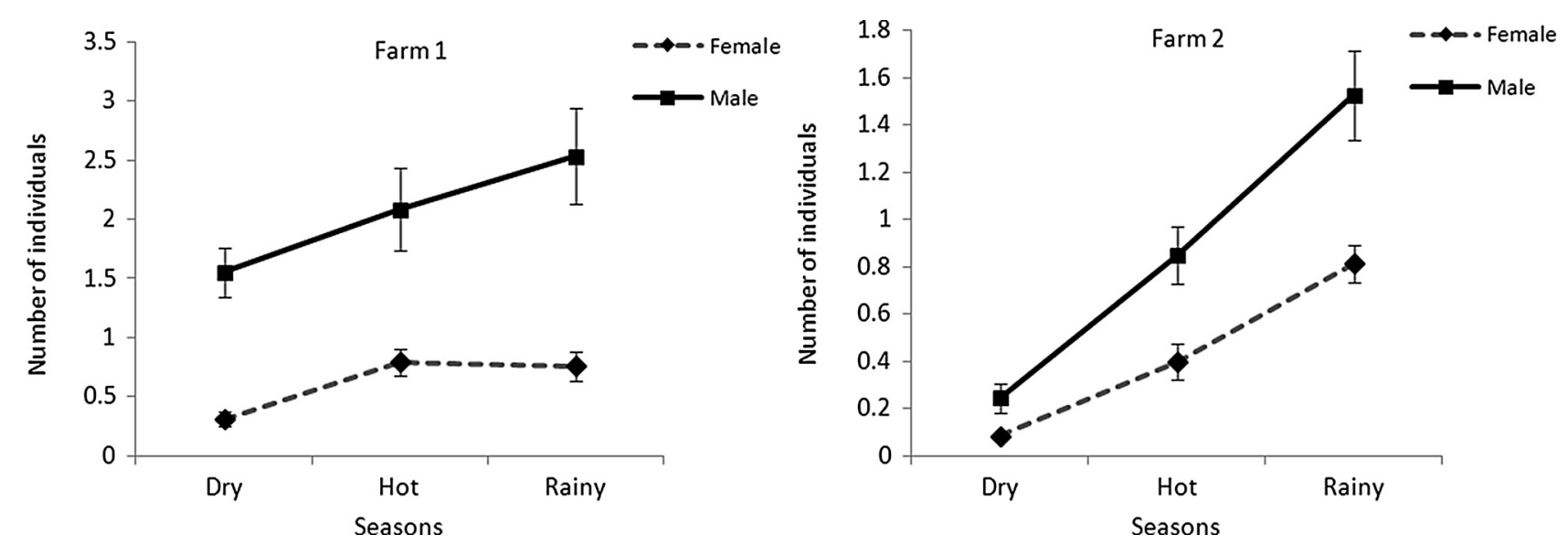

Figure 5. Mean numbers \pm standard error bars of Stomoxys calcitrans males and females collected during three seasons on two dairy farms.
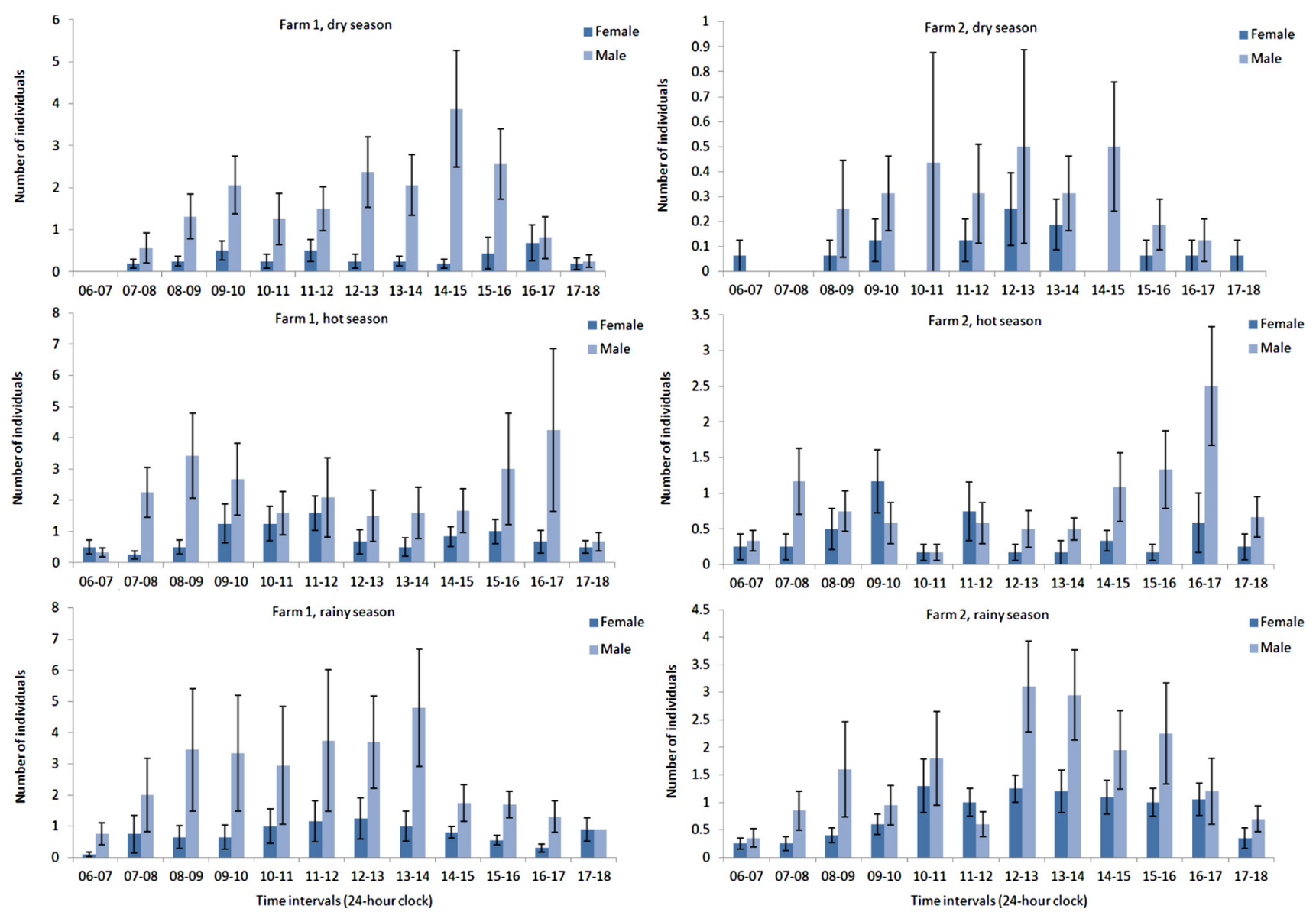

Figure 6. Mean numbers \pm standard error bars of Stomoxys calcitrans males and females collected during one-hour intervals in three seasons on two dairy farms.

at $0800-1000$ and $1400-1600 \mathrm{~h}$ while female activity increased throughout the day until $1600 \mathrm{~h}$, when the activity of both males and females declined steadily until it was dark. Masmeatathip et al. [11] reported bimodal activity of $S$. indicus and $S$. sitiens with population peaks in the early morning and in the late afternoon. This finding was similar to that observed in this study. Stable flies require blood for successful mating and ovarian development, but also require nectar as a supplemental energy source for flight activity and successful blood-feeding [20]. Müller et al. [14] conducted studies on the diurnal feeding behavior of three Stomoxys species in Mali and found bimodal blood-feeding and unimodal sugar-feeding activity periods. The differences in feeding activity patterns were dependent upon the protein and nectar sources, local conditions, sampling methods 
Table 2. Stepwise multiple regression analysis with correlation between total number of Stomoxys calcitrans and weather parameters in Muak Lek district, Saraburi Province from September 2010 to August 2011.

\begin{tabular}{|c|c|c|c|c|c|c|}
\hline Effect & $b$ & $S E$ of $b$ & Beta & $t$ & $p$ & \\
\hline Intercept & -17.266 & 4.57 & & -3.778 & 0.000 & \\
\hline Relative humidity (\%) & 0.337 & 0.062 & 0.336 & 5.481 & 0.000 & \\
\hline \multirow[t]{2}{*}{ Light intensity (lux) } & 0.00006 & 0.000 & 0.208 & 3.39 & 0.001 & \\
\hline & $\begin{array}{l}R^{2} \\
0.1\end{array}$ & $\begin{array}{c}S S \\
3,945.72\end{array}$ & $\begin{array}{l}d f \\
2\end{array}$ & $\begin{array}{c}M S \\
1,972.86\end{array}$ & $\begin{array}{c}F \\
15.89\end{array}$ & $\begin{array}{c}p \\
0.000\end{array}$ \\
\hline
\end{tabular}
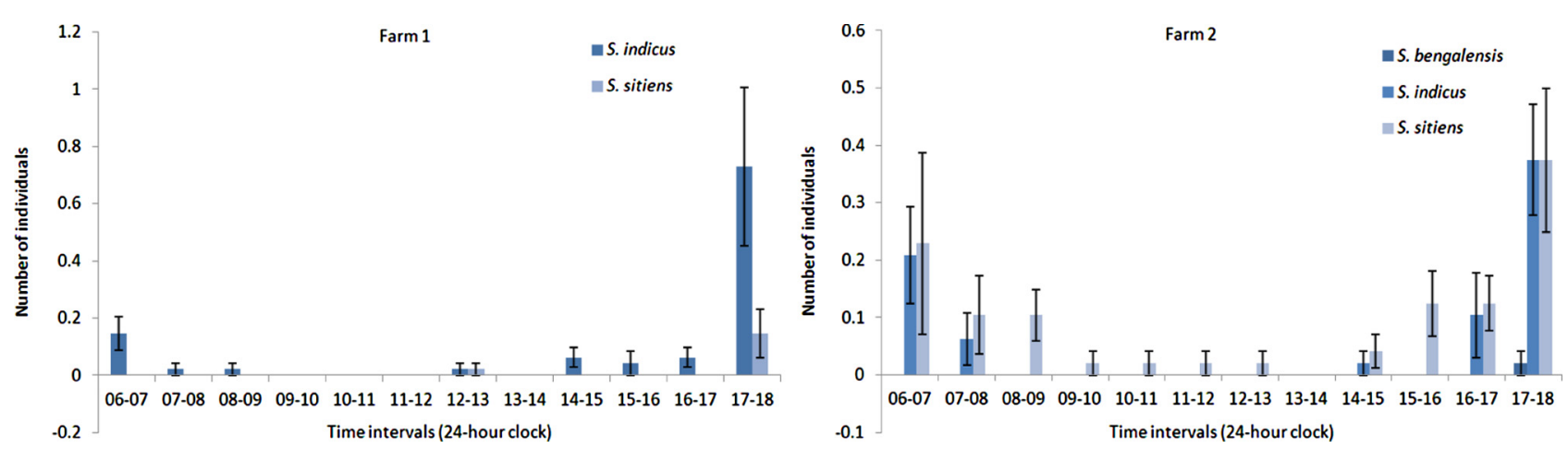

Figure 7. Mean numbers \pm standard error bars of Stomoxys spp. males and females collected during one-hour intervals on two dairy farms from September 2010 to August 2011.

and seasons. Analysis of the data showed the abundance of S. calcitrans was significantly and positively correlated with relative humidity and light intensity although the relationship was weak $(R=0.317)$. There were probably other factors that affected the flight activity patterns of this species. The current study has provided a step in the evolution of planning and developing control systems for insects.

Acknowledgements. We thank the Thailand Research Fund (Senior Research Scholar: RTA5280007) for financial support. We also thank Mr. Dan Guyot who assisted with English editing in a draft and the owners of the dairy farms for permission to sample on their land.

\section{References}

1. Beresford DV, Sutcliffe JF. 2008. Stable fly (Stomoxys calcitrans: Diptera, Muscidae) trap response to changes in effective trap height caused by growing vegetation. Journal of Vector Ecology, 33, 40-45.

2. Bruce WN, Decker GC. 1958. The relationship of stable fly (Stomoxys calcitrans) abundance to milk production in dairy cattle. Journal of Economic Entomology, 51, 269-274.

3. Campbell JB, Berry IL, Boxler DJ, Davis RL, Clanton DC, Deutscher GH. 1987. Effects of stable flies (Diptera: Muscidae) on weight gain and feed efficiency of feedlot cattle. Journal of Economic Entomology, 80, 117-119.

4. Campbell JB, Skoda SR, Berkebile DR, Boxler DJ, Thomas GD, Adams DC, Davis R. 2001. Effects of stable flies (Diptera: Muscidae) on weight gains of grazing yearling cattle. Journal of Economic Entomology, 94, 780-783.

5. Catangui MA, Campbell JB, Thomas GD, Boxler DJ. 1997. Calculating economic injury levels for stable flies (Diptera:
Muscidae) on feeder heifers. Journal of Economic Entomology, 90, 6-10.

6. Cruz-Vazquez C, Mendoza IV, Parra MR, Garca-Vazquez Z. 2004. Influence of temperature, humidity and rainfall on field population trend of Stomoxys calcitrans (Diptera: Muscidae) in a semiarid climate in Mexico. Parasitologia Latinoamericana, 59, 99-103.

7. Gilles J, David JF, Duvallet G, Rocque S De La, Tillard E. 2007. Efficiency of traps for Stomoxys calcitrans and Stomoxys niger niger on Reunion Island. Medical and Veterinary Entomology, $21,65-69$.

8. Laveissière C, Grébaut P. 1990. Recherches sur les pièges à glossine (Diptera: Glossinidae). Mise au point d'un modèle économique: le piège «Vavoua ». Tropical Medicine and Parasitology, 41, 185-192.

9. Linnaeus C. 1758. Systema naturae per regna tria naturae, secundum classis, ordines, genera, species, cum characteribus, differentiis, synonymis, locis. 10th edn., Vol. 1, Laurentii Salvii, Stockholm.

10. Lysyk TJ. 1993. Seasonal abundance of stable flies and house flies (Diptera: Muscidae) in dairies in Alberta, Canada. Journal of Medical Entomology, 30, 888-895.

11. Masmeatathip R, Gilles J, Ketavan C, Duvallet G. 2006. First survey of seasonal abundance and daily activity of Stomoxys spp. (Diptera: Muscidae) in Kamphaengsaen Campus, Nakornpathom Province, Thailand. Parasite, 13, 245-250.

12. Muenworn V, Duvallet G, Thainchum K, Tuntakom S, Akratanakul P, Chareonviriyaphap T. 2010. Stable fly (Diptera: Muscidae) distribution in Thailand. Kasetsart Journal (Natural Science), 44, 44-52.

13. Muenworn V, Duvallet G, Thainchum K, Tuntakom S, Tanasilchayakul S, Prabaripai A, Akratanakul P, Sukonthabhirom S, Chareonviriyaphap T. 2010. Geographic distribution of stomoxyine flies (Diptera: Muscidae) and diurnal activity of 
Stomoxys calcitrans in Thailand. Journal of Medical Entomology, 47, 791-797.

14. Müller GC, Hogsette JA, Beirt JC, Traore SF, Toure MB, Traore MM, Bah S, Doumbia S, Schlein Y. 2012. Attraction of Stomoxys sp. to various fruits and flowers in Mali. Medical and Veterinary Entomology, 26, 178-187.

15. Picard F. 1908. Description de deux nouveaux Stomoxys du Bengale (Dipt.), Bulletin de la Societé Entomologique de France, 20-21.

16. Pitzer JB, Kaufman PE, Hogsette JA, Geden CJ, Tenbroeck SH. 2011. Seasonal abundance of stable flies and filth fly pupal parasitoids (Hymenoptera: Pteromalidae) at Florida Equine Facilities. Journal of Economic Entomology, 104, 1108-1115.

17. Rondani C. 1873. Muscaria exotica Musei Civici Januensis observata et distinct a Prof. Camillo Rondani. Fragmentum I. Species aliquae in Abyssinia (Regione Bogos) lectae a Doct. O. Beccari et March. O. Antinori, anno 1870-71. Annali del Museo Civico di Storia Naturale Giacomo Doria, Genova, 4, 282-294.

18. Skoda SR, Thomas GD, Campbell JB. 1991. Developmental sites and relative abundance of immature stages of the stable fly (Diptera:Muscidae) in beef cattle feedlot pens in eastern Nebraska. Journal of Economic Entomology, 84, 191-197.
19. Sumba AL, Mihok S, Oyieke FA. 1998. Mechanical transmission of Trypanosoma evansi and T. congolense by Stomoxys niger and S. taeniatus in a laboratory mouse model. Medical and Veterinary Entomology, 12, 417-422.

20. Taylor DB, Berkebile D. 2008. Sugar feeding in adult stable flies. Environmental Entomology, 37, 625-629.

21. Traversa D, Otranto D, Iorior R, Carluccio A, Contri A, Paoletti B, Bartolini R, Giangaspero A. 2008. Identification of the intermediate hosts of Habronema microstoma and Habronema muscae under field conditions. Medical and Veterinary Entomology, 22, 283-287.

22. Tumrasvin W, Shinonaga S. 1978. Studies on medically important flies in Thailand V. On 32 species belonging to the subfamilies Muscinae and Stomoxyinae including the taxonomic keys (Diptera: Muscidae). Bulletin of Tokyo Medical and Dental University, 25, 201-227.

23. Wieman GA, Campbell JB, Deshazer JA, Berry IL. 1992. Effects of stable flies (Diptera: Muscidae) and heat stress on weight gain and feed efficiency of feeder cattle. Journal of Economic Entomology, 85, 1835-1842.

24. Zumpt F. 1973. The Stomoxyine Biting Flies of the World. Diptera: Muscidae, Taxonomy, Biology, Economic Importance and Control Measures. Gustav Fischer Verlag, Stuttgart, Germany.

Cite this article as: Phasuk J, Prabaripai A \& Chareonviriyaphap T: Seasonality and daily flight activity of stable flies (Diptera: Muscidae) on dairy farms in Saraburi Province, Thailand. Parasite, 2013, 20, 17.

\section{- PARASTE}

An international open-access, peer-reviewed, online journal publishing high quality papers on all aspects of human and animal parasitology

Reviews, articles and short notes may be submitted. Fields include, but are not limited to: general, medical and veterinary parasitology; morphology, including ultrastructure; parasite systematics, including entomology, acarology, helminthology and protistology, and molecular analyses; molecular biology and biochemistry; immunology of parasitic diseases; host-parasite relationships; ecology and life history of parasites; epidemiology; therapeutics; new diagnostic tools.

All papers in Parasite are published in English. Manuscripts should have a broad interest and must not have been published or submitted elsewhere. No limit is imposed on the length of manuscripts.

Parasite (open-access) continues Parasite (print and online editions, 1994-2012) and Annales de Parasitologie Humaine et Comparée (1923-1993) and is the official journal of the Société Française de Parasitologie. 